3 Rutter M, Quinton D. Psychiatric disorders: ecological factors and concepts of causation. In Ecological Factors in Human Development (ed H McGurk): 173-87. North-Holland, 1977.

4 Dogra N, Vostanis P, Karnik N. Childhood and adolescent psychiatric disorders. In Textbook of Cultural Psychiatry (eds D Bhugra, K Bhui): 301-13. Cambridge University Press, 2007.

5 Department of Health, Department for Education and Skills. The National Service Framework for Children, Young People and Maternity Services. Department of Health, 2004.

6 Department for Education and Skills. Every Child Matters: Change for Children. TSO (The Stationery Office), 2004.
7 Stevens GWJM, Vollebergh WAM. Mental health in migrant children. J Child Psychol Psych 2008; 49: 276-94.

8 Green H, McGinnity A, Meltzer H, Ford T, Goodman R. Mental Health of Children and Young People in Great Britain, 2004. Palgrave Macmillan, 2005.

9 Hölling H, Kurth BM, Rothenbeger A, Becker A, Schlack R.

Assessing psychopathological problems of children and adolescents from 3 to 17 years in a nationwide representative sample: results of the German health interview and examination survey for children and adolescents (KiGGS). Eur Child Adolesc Psychiatry 2008; 17 (suppl 1): 34-41.

10 Singh SP. Shooting the messenger: the science and politics of ethnicity research. Br J Psychiatry 2009; 195: 1-2.

\section{psychiatry} in pictures

\title{
Dr Harley Quinn, the villain from Gotham City with dependent personality disorder
}

José Alexandre S. Crippa and Jaime E. C. Hallak

Dr Harley Quinn is a super-villain, enemy of Batman, whose name was suggested by the Joker as a play with the word 'harlequin' and her original name, Harleen Quinzel. The character was created by Paul Dini and Bruce Timm in Batman: The Animated Series, later adapted into the DC Comics' Batman series. Dr Quinn usually dressed as a jester and occasionally appeared in some of Batman's comic books, television episodes and in video games based on the animated series. In the story, Harleen Quinzel did her psychiatry training at Arkham University, and later worked as a psychiatrist at the Arkham Asylum where as an intern she met the Joker as her patient. She quickly fell in love and indiscriminately

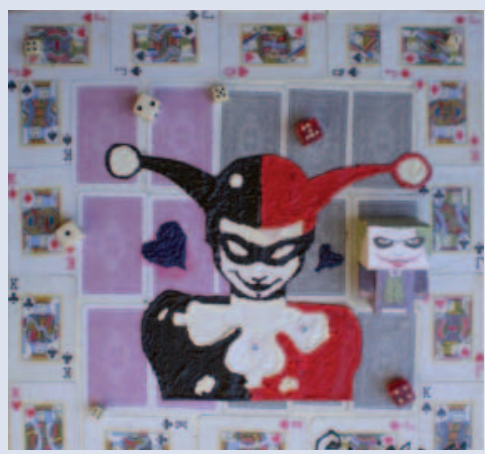

attached to him during their psychotherapy sessions, finally helping him to escape from the asylum. Afterwards, she changed her name to Harley Quinn, becoming Joker's frequent accomplice and girlfriend. However, the Joker frequently screams at, hazes and maltreats her in their fickle relationship. In these situations, she responds with indulgent tolerance, always submitting to his abuse and intimidation to avoid abandonment.

As opposed to drama movies and TV series, psychiatrists are not common characters in comics, especially in the role of villains, and here again Dr Harley Quinn is the stereotype of a dysfunctional psychiatrist. In particular, she has traits of dependent personality disorder, as well as the antisocial aspects expected in a villain. Luckily, Harley Quinn is not one of the most popular villains in the comic world and hopefully Batman will seek another psychiatrist to solve his neurotic problems.

Mosaic, Dr Harley Quinn, created by José Alexandre S. Crippa, 2011, $40 \times 40$ cm; playing cards, dice, papercraft, toys, coloured glue, mounted on canvas. 